\title{
KOMPLEX MONITORINGRENDSZER HASZNÁLATA VASÚTI FELÉPÍTMÉNY VIZSGÁLATÁBAN AZ IPAR 4.0-VAL ÖSSZHANGBAN
}

\section{USING A COMPLEX MONITORING SYSTEM FOR RAILWAY STRUCTURE INVESTIGATION IN ACCORDANCE WITH 4.0.}

\author{
Tokody Dániel ${ }^{1}$, Nyikes Zoltán ${ }^{2}$, Kovács Tünde ${ }^{3}$ \\ ${ }^{1}$ Óbudai Egyetem, Biztonságtudományi Doktori Iskola, 1081 Budapest Népszínház \\ u.8., tokody.daniel@mav.hu \\ 2 Óbudai Egyetem, Biztonságtudományi Doktori Iskola, 1081 Budapest Népszinház \\ u.8.,nyikeszoli@gmail.com \\ ${ }^{3}$ Óbudai Egyetem, Bánki Donát Gépész és Biztonságtechnikai Mérnöki Kar, 1081 \\ Budapest Népszínház u. 8., kovacs.tunde@bgk.uni-obuda.hu
}

\begin{abstract}
The provision of railway transport and transport a priority part of the infrastructure, not only in our country, but all over the world. The rails must be checked because of the damages resulted from the continuous demand. The continuous in-situ monitoring enables the safe operation, which information obtained in the monitoring, management and processing of data after regulates the rail system. Loss or change of the measured data can cause a disaster, so by monitoring the information security is a top priority.
\end{abstract}

Keywords: real-time rails health monitoring, rail diagnosis, Industry 4.0, smart rail technology, data-driven railway systems

\begin{abstract}
Absztrakt
A vasúti szállítás és közlekedés biztosítása az infrastruktúra kiemelt fontosságú része nemcsak hazánkban, de a világ minden részén. A sínpályákat az igénybevételekből eredő károsodások miatt folyamatosan ellenőrizni kell. A folyamatos in situ ellenőrzés lehetőséget nyújt a biztonságos üzemeltetésre, mely a monitorozás során kapott információk, adatok kezelése és feldolgozása után szabályozza a vasúti rendszert. A mért adatok elvesztése vagy megváltozása katasztrófát is okozhat, ezért a monitorozás során az információbiztonság kiemelt fontosságú.
\end{abstract}

Kulcsszavak: valós idejü sínmonitoring, sindiagnosztika, Ipar 4.0, okos vasúti technológiák, adatalapú vasúti rendszer létrehozása

\section{Bevezetés}

Wolfgang Wahlster, a Német Mesterséges Intelligencia Kutatóközpont vezetője előadásában az Ipar 4.0-ról beszélt már 2013-ban. Lényegében meglátása szerint a 4. ipari forradalmat éljük, ami az ipari au- tomatizálás tekintetében a kiberfizikai rendszerek megvalósítását jelenti [1].

Cikkünk címe láttán felmerül a kérdés, hogy mi a kapcsolat a vasúti felépítmény vizsgálata és az Ipar 4.0 között. Az Ipar 4.0 létrejötte a digitalizáció folyamatához köthető. A digitális forradalom, a negyedik 
ipari forradalom vagy, ahogy nevezzük „Ipar 4.0” a teljes gazdaságunkat átalakítja. A gazdaság mindig is erős kapcsolatban állt a közlekedés fejlettségével. Gondoljunk csak arra, ha egy régióban például autópálya vagy vasúti pálya épül, ezáltal a közlekedés folyamatai beindulnak, milyen hatással van az a teljes ott élö társadalom egészére. Ez a katalitikus hatású változás következik be a digitalizáció vasúti területen történő elterjedése esetén is. [2]

Úgy, ahogy az 1946-os évektől Norbert Wiener által először megfogalmazott kibernetika megváltoztatta a vasút világát, meglátásunk szerint úgy fogja a digitalizáció is átalakítani a vasúti ipart, a vasúti infrastruktúrát, illetve a vasúttal kapcsolatos tevékenységek egészét. Nevezhetjük ezt a folyamatot a közlekedési rendszereket tekintve digitalizációnak, intelligens vagy okos rendszerek létrehozásnak, vasúti eszközök internetének (IoT), intelligens közlekedési rendszerek kialakításának vagy akár okos mobilitásnak. Lényegében arról van szó, hogy a valós fizikai világ és a virtuális (digitális, kiber) világ közötti kapcsolatok létrejötte az élet összes területén megjelenik. Így nemcsak a városokban, közlekedésben, de még a vasúti alkalmazásokban is, létrehozva a hálózatba kapcsolt kooperatív intelligens közlekedést, amelynek egyik fontos eleme a fizikai környezet érzékelésére szolgáló érzékelő hálózaton alapuló és a fizikai rendszerbe is beavatkozni képes automatikus felügyeleti és irányítórendszer megvalósítása.

\subsection{Preventív valós idejú pályaállapot monitoringrendszer kialakításá- nak kérdései}

A vasúti pálya monitoring jelentős szerepet tölt be a vasúti pálya kiépítési állapotának fenntartásában, a megfelelő színvonalú és biztonságos vasúti közlekedés megvalósításában. A vasúti pályahibából eredő szolgáltatásromlás jelentős negatív hatáso- kat és plusz költségeket jelent a vasúti szolgáltatást nyújtóknak.

Ugyanakkor a ma alkalmazott vizsgálati módszerek bonyolult mérővonatokba épített szerkezeteket igényelnek, amelyek üzemeltetése, futásigénye, szakemberek általi felügyelete többletköltségként jelentkezik a vasúti pályát üzemeltető számára. Ennek csökkentésére jó lehetőség mutatkozik egy kompakt kivitelü mérō- és felügyeleti rendszer kialakításával. Ezt az új kialakítású rendszert nem külön mérővonatokra szerelt berendezések alkalmazásával szeretnénk létrehozni, hanem a mai magyar vasúton használt összes mozdonytípusra felszerelhető változattal kívánjuk megvalósítani. A rendszer előnye, hogy az amúgy is futó mozdonyokon elhelyezve folyamatos, valós idejü adatokat szolgáltathat a teljes bejárt pályaszakaszokról, ezzel mintegy állandó felügyelet alatt tartva a vasúti infrastruktúra ezen részét. Ennek előnye azonnal látszik, hiszen a mérővonatok csak bizonyos időnként képesek végigjárni a különböző vasúti pályaszakaszokat.

Ezért mind a mai napig vonalgondozó kollégák járják a vasútvonalakat. A vonalgondozó tevékenysége a vonalbejárás, melynek során megfigyeli a vasúti pályát és annak tartozékait, a vasúti ürszelvényt és annak szabad voltát a vasúti forgalom biztonságának garantálása végett. Mondani sem kell, az emberi érzékelés korlátait miatt ez a fajta tevékenység nem derítheti fel az összes pályaproblémát.

A vasúti pályáról folyamatosan gyüjtött adatokat a mozdony vezetőjének hathatós közreműködése nélkül automatikus módon GSM-R kommunikáción keresztül egy zártcélú felügyeleti rendszer számára továbbíthatjuk. A nagy mennyiségü adat feldolgozását követően platform független felületen jeleníthetjük meg az egyes vasútvonalakon regisztrált mérési eredményeket. A rendszer kialakításából adódóan akár egy vonalon haladó összes mozdony által mért adatot egy helyen ábrázolhatjuk. Így az egyszeri 
vagy ritka mérésből fakadó problémák nem jelentenek gondot a rendszerben. Kiváltképpen így van ez egy forgalmasabb vonalszakasz esetén.

Nem szükséges a vasútvonal mérése kapcsán külön pályakapacitást felhasználni, így ebben az időben a pályát üzemeltető vasúti társaság saját tevékenységét végezheti. A rendszer a mai felügyeleti rendszerek minden elönyével is párosul. A gyüjtött adatok feldolgozásával olyan prediktív riportok állíthatók elő, amelyek segítik a pályaszakaszok üzemeltetését, karbantartását, hibaelhárítását, felújításának tervezését stb.

\section{Síndiagnosztikai kihívások}

Milyen sín-, illetve pályadiagnosztikai funkciókat valósíthatunk meg az említett rendszerrel?

Ilyen a vasúti sín teljes körü vizsgálata. $\mathrm{Az}$ 1. ábrán egy sínfejhibát láthatunk, amely súlyos problémát okoz a nagy sebességủ és nagy teljesítményủ mozdonyok által továbbított vasúti szerelvények közlekedésében.

Sínek, aljak, kapcsolószerek, ágyazat megfigyelésére képessé tehető a felügyeleti rendszer.

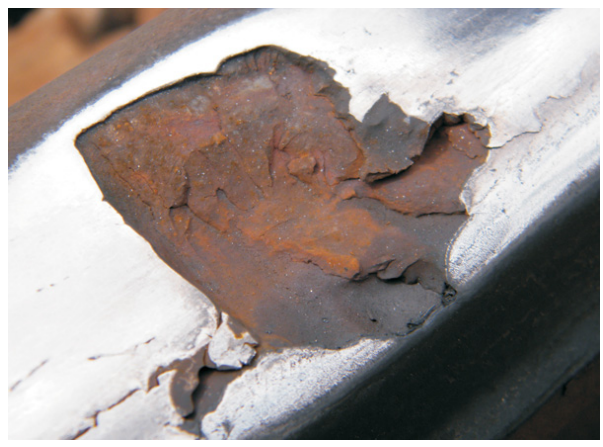

1. ábra. Vasúti sinfejhiba [3]

A 2. ábrán a sínleerősítési hiányosságok láthatók.

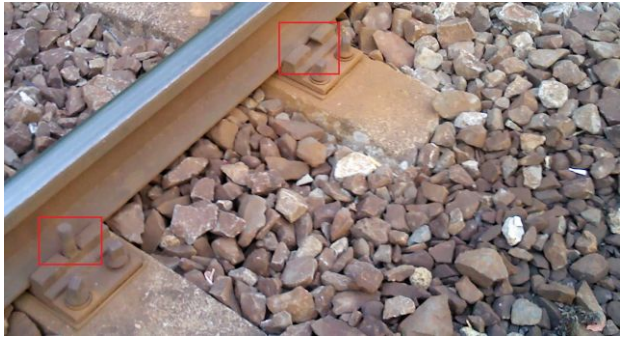

2. ábra. Vasúti pálya sinleerösitési hiányossággal [4]

A vasúti pályában keletkező egyéb hibák automatikus feltárása. A vasúti pálya nem megfelelő víztelenítése okán keletkező ágyazateliszaposodás felderítésére is alkalmassá tehető a rendszer. Segítségével pontos adatbázist hozhatunk létre az említett problémák minél hamarabb történő szakszerü kezelésére.

A 3. ábrán a vasúti ágyazat kezdődő eliszaposodását láthatjuk. A rendszer képessé tehető a vasúti pályába épített egyéb eszközök állapotának felmérésére is. Például a hazai vasúti technikában alkalmazott szigeteltsínek állapotának vizsgálatára.

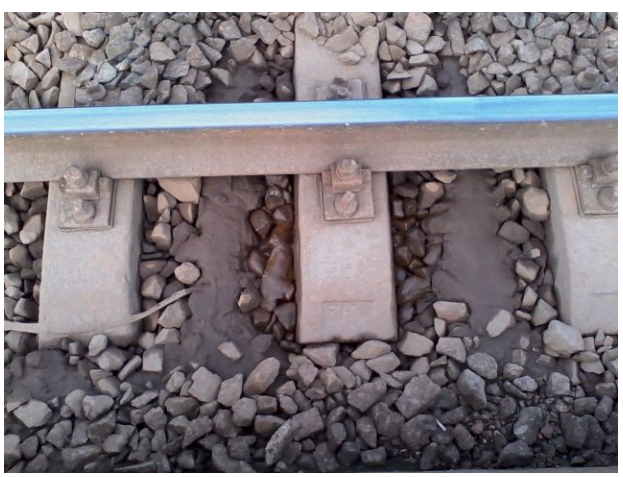

3. ábra. Vasúti ágyazat eliszaposodásának felismerése (saját ábra, Gödöllö állomás 2016.08.12.)

A 4. ábrán a sínfejnek egy szigetelő hevederkötésnél kialakuló összeverödését figyelhetjük meg. 


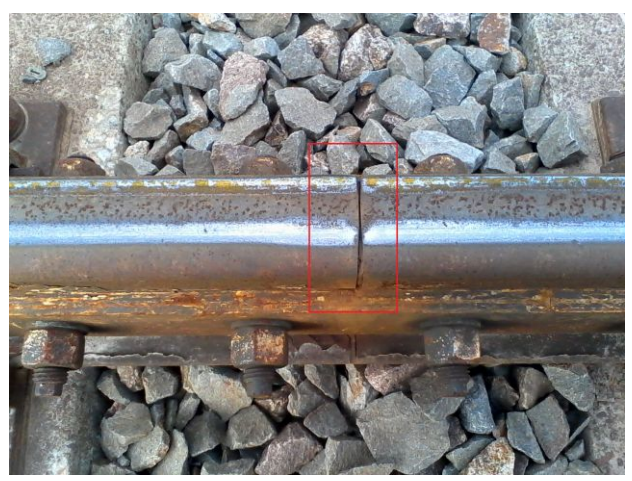

4. ábra. Vasúti pályába épített berendezések vizsgálata (saját ábra, Gödöllö állomás 2016.08.12.)

Nemcsak a szigeteltsínek vizsgálata, felügyelete valósítható meg, hanem például a balízok (elektromágneses jeladó a sínpár között), a kitérökbe épített hajtómüvek, egyéb szerelvények vizsgálata is.

A rendszerben gyüjtött adatok kiértékelése módot adhat arra, hogy a vasúti pályahibából adódó balesetek megelőzhetők legyenek. Egy ilyen síntörésből fakadó baleset képét látjuk az 5. ábrán.

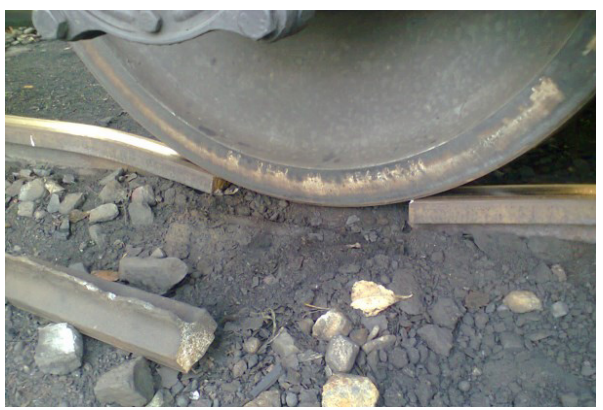

5. ábra. Széles nyomtávolságú vasúti pálya meghibásodása, jármü alatti sintörés (Záhony, 2013.10.10-én) [5]

\section{Vasúti sínek állapotfelügyelete, mérési lehetőségek és módsze- rek}

A sínek károsodási formái igen különbözőek lehetnek. Az acélsín üzemszerüen a szintén acél vasúti kerékkel érintkezik szá- raz (az időjárási csapadéktól eltekintve) gördülő és csúszó mozgásban. A felületek folyamatosan ismétlődő és váltakozó terhelésnek kitettek, mely fárasztó igénybevételt okoz. A rugalmas képlékeny alakváltozás finom szövetszerkezeti változásokat okozhat, melyek befolyásolják a mechanikai tulajdonságokat [6][7]. Emellett nem hanyagolható el az a másik szintén a sínpályát terhelő igénybevétel (,zakatolás”), mely a sín alapjának, a vasúti ágyazatnak a károsodása miatt ébredő fárasztó igénybevétel, mely esetben már az üzemi terheléstől eltérő lengő és lüktető igénybevétel lép fel. A két egymástól eltérö fárasztó igénybevétel szuperponálódása katasztrofális károsodási eseményekhez vezethet.

A használatban lévő sínpályák károsodásának vizsgálata csak roncsolásmentes vizsgálatokkal végezhető el. Azoknak a vizsgálati módszereknek a száma, melyekkel a hibák kimutathatók, igen széles. A vizsgálati módszer kiválasztásakor mindig figyelembe kell vennünk a vizsgálandó anyag kémiai összetételét, a gyártási módból adódó strukturális sajátosságait, valamint a geometriájából is származó feszültségállapotát.

\subsection{Szemrevételezés (optikai kamera alkalmazása)}

A legelterjedtebb roncsolásmentes vizsgálati módszer a szemrevételezés. Ebben az esetben általában a vizsgáló személy végzi a vizsgálatot, de alkalmazhatunk optikai kamerát, valamint képelemző rendszert. Ebben az esetben etalon képpel történö összehasonlítás történik, melyhez megfelelő megvilágítás szükséges. A sín felületére kerülő szennyeződések és megváltozó fényviszonyok a vizuális képelemzés eredményét befolyásolhatják.

\subsection{Ultrahangos vizsgálat}

Az ultrahangos vizsgálatnak két típusát különböztethetjük meg, az egyik, amikor a vizsgálófej csatoló folyadékkal a vizsgálan- 
dó darab felületéhez érintkezik, a másik pedig amikor nem szükséges az érintkezés. Mindkét esetben a nagy frekvenciás ultrahang azon tulajdonságát használjuk ki, hogy a közegben terjedve annak határáról visszaverödik.

\subsection{Akusztikus emissziós vizsgálat}

A repedések, törések keletkezésénél a rugalmas energia felszabadulása hangkibocsátással jár. A kerék-sín kapcsolat során keletkezö hangok rögzítése és „,etalon” jelsorozattal való összehasonlítása is szolgáltathat információt a sín állapotát illetően, természetesen a zavaró jelek kiszürése elengedhetetlen.

\section{4. Örvényáramos vizsgálat}

Elektromosan vezető anyagok esetén alkalmazható, melyekben az időben változó mágneses tér áramot indukál. Ezt az áramot örvényáramnak nevezzük. Az örvényáram is gerjeszt mágneses teret, mely visszahat a gerjesztő mágneses térre, illetve az azt létrehozó áramra. Az áramot mérni lehet, az eredményből különböző anyaghibákra vagy anyagtulajdonságokra és azok megváltozására lehet következtetni[6].

A vizsgálat korlátja, hogy csak a felületi és a felülethez közeli eltérések kimutatására alkalmas, így a vizsgált darab belsejében keletkezett repedés, hiba nem mutatható ki.

\subsection{Radarvizsgálat}

A vizsgálat a földradarral azonos elvü geofizikai módszer, amely radar impulzusok segítségével gyüjt információkat a pálya állapotáról, ahhoz hasonlóan, mint az ultrahangos technikánál. A kapott eredmények alapján a felszín alatti repedések, hibák mutathatóak ki. A georadar elektromágneses rövidhullámot bocsát ki, mely a nem egyforma dielektromos állandójú rétegekben visszaverődik. A dielektromos állandót többnyire a talaj nedvességtartalma (minél magasabb a nedvességtartalom, annál magasabb a dielektromos állandó), ki- sebb mértékben pedig a talaj sürüsége és szerkezete határozza meg.

A georadaros roncsolásmentes vizsgálattal kimutatható a vasúti pálya romlásának két fö tényezője: az ágyazat és az alépítmény megnövekedett nedvességtartalma, illetve annak felaprózódása és szennyezettsége, aminek következménye a teherbíráscsökkenés. Kimutathatók továbbá a különböző szerkezeti rétegekben végbemenő tönkremeneteli folyamatok, rétegvastagság megváltozása, altalajsüllyedés, vízzsákok kialakulása, továbbá a felszín alatti közmükeresztezések, akadályok, tereptárgyak jelenléte stb [6] [7].

\subsection{Termográfiai vizsgálat}

Infravörös fény alkalmazásával járó termográfiai vizsgálat szintén jó eredményt adhat. Ezzel a módszerrel is csak a sínfelületen létrejövő és ahhoz közeli hibák mutathatók ki. A termográfiás, termovíziós eljárások általában azon az elven alapulnak, hogy egy anyag, pl. lemez egyik oldalának melegítésekor a belső anyaghibáktól mentes helyeken a termikus energia akadálytalanul átjuthat, míg a belső anyaghibás helyeken hőtorlódás keletkezik. Ez utóbbi jelenségnek az az oka, hogy a hibahelyeket kitöltő levegőnek a hővezetőképessége a fémeknek csak mintegy tized-, esetleg század-része. A termovíziós eljárás az infravörös színképtartománynak egy sávját hasznosítja. A rövidhullám-hosszak felé a nyaláb érzékelési határa a látható tartományban a mélyvörösben van. A hosszúhullám-tartomány felé a határ beleolvad a milliméter nagyságrendủ (mikrohullámú) sávba. Az infravörös hullámsávot általában négy csoportra szokták felosztani, úgymint: közeli $(10,75 \ldots 3$ $\mu \mathrm{m})$, közepes $(3 \ldots 6 \mu \mathrm{m})$, távoli $(6 \ldots 15 \mu \mathrm{m})$ és a legtávolibb $(15 \ldots 1000 \mu \mathrm{m})$ tartományra. Az említett tartományok közül a termovíziós eljárás a $3 \ldots .6 \mathrm{~nm}$ hullámhoszszúságú közepes infravörös tartományban kisugárzott energiát transzformálja láthatóvá, és jeleníti meg képernyőn. 


\subsection{Radiológiai vizsgálat}

A röntgenvizsgálat vagy izotópos vizsgálatok a sínek teljes keresztmetszetét illetően információt tudnak szolgáltatni az anyagfolytonossági hiányok tekintetében. A mikrorepedések kimutatására azonban nem alkalmas, és az anyagvastagság növekedésével csökken a kimutatható hibák mérete. $\mathrm{Az}$ általunk tervezett monitoringmódszerhez nem alkalmazható, mivel alkalmazása során veszélyt jelenthet a környezetében található élölényekre, a vizsgálat elvégzése szigorú biztonsági szabályhoz kötött. A vonat nagy sebessége leképezési korlátot jelent.

\subsection{Lézeres hibakereső vizsgálat}

Ennek a vizsgálatnak az alkalmazhatósága is korlátozott, a sínfelület károsodásának ellenőrzésére lehet alkalmas. Mivel ennél a vizsgálatnál az emberi szemre és bőrre káros fényspektrumot alkalmazunk, igen gondos biztonságtechnikai követelményeknek is meg kell felelni.

\section{A javasolható vizsgálati rendszer}

A felsorolt vizsgálati módszerek egyike sem alkalmas önmagában, hogy a sínpálya állapotáról egyértelmü információkat szolgáltasson. Javasolt ezért egy kombinált vizsgálati módszer, mely esetén nemcsak a sín felületi rétegeinek károsodásáról kaphatunk képet, hanem a sínpálya egészérôl tudunk információt gyüjteni.

\section{Kapott adatok, mérési eredmé- nyek biztonságos továbbítása}

Az ipari adatok, információk védelmére van számos, már létező bevált módszer. Az alapelvek itt is ugyanúgy érvényesülnek. Meg kell felelni annak a bizonyos hármas követelménynek, ami nem más, mint a Sértetlenség, a Bizalmasság és a Rendelkezésre állás elve. Ezt manapság a szakértők még kiegészítik a Letagadhatatlanság elvével is. A négy alapelvnek és ezek megfelelőségé- nek köszönhetően alkalmazhatók azok a védelmi megoldások, amelyek az ipari adatok védelmét szolgálják. [8]

\subsection{Miért fontos az információbizton- ság}

Nem szabad megfeledkezni arról sem, hogy - mint minden védelmi megoldás alkalmazása előtt - kockázati elemzést kell lefolytatni a rendszerre vonatkozóan. A kockázatelemzésre azért van szükség, hogy előre megpróbáljunk modellezni azokat a lehetőségeket, amelyek a rendszerünk biztonságát veszélyeztetik. Ez által jól beazonosíthatóak azok a sérülékenységi pontok, amelyek veszélyt jelentenek a rendszerre. Ezek nemcsak ember által okozott károk, hanem lehetnek természeti vagy anyagfáradásból adódó károk, esetleg a nem megfelelő tervezésből adódó problémák [9].

\subsubsection{Fizikai biztonság}

A fizikai biztonság tekintetében az egyenszilárd védelem biztosítását kell megoldani, valamint a héjszerü védelmet szükséges alkalmazni. Tehát a fizikai biztonság az a terület, ahogy az adatok, információk hozzáférését fizikai akadályokkal gátoljuk azok számára, akik nem jogosultak a védendő adathoz, információhoz való hozzáférésre.

\subsubsection{Személyi biztonság}

A személyi biztonság alatt az adott személyek megbízhatóságának és a felmerülő vizsgálati módszernek az összességét értjük. Ezek alapján eldönthető, hogy mielőtt az adott személynek, a szenzitív, védendő adatokhoz, információkhoz való hozzáférése megtörténne, megállapítást nyerjen a megbízhatósága, azaz a rendelkezésére bocsátott adatokkal, információkkal nem fog visszaélni, vagy nem tesz bennük szándékosan kárt. 


\subsubsection{Adminisztratív biztonság}

Az adminisztratív biztonság azt jelenti, hogy a különböző eljárásrendek meglétét szükséges biztosítani. A jogszabályi és/vagy szabványok által biztosítottak alapján a saját eljárásrend kidolgozottsága az üzemeltetésre és az üzemmeneti folytonosság biztosítása céljából $(\mathrm{BCM})$. Továbbá ide tartozik az üzemeltetők és felhasználók képzése és azok tervezése.

\subsubsection{Elektronikus információbiztonság}

Az elektronikus információbiztonság az adatok, információk elektronikus, digitális megjelenési formájának a védelmét jelenti az adat, információ keletkezésének helyétől a különböző átviteli utakon keresztül a végfelhasználóval bezárólag a megfelelő és szükséges logikai és vírusvédelmet is ideértve, valamint a megfelelő adatrejtést, úgymint a titkosítás/rejtjelezés. Idetartozik az adat tárolása, a biztonsági mentés, a felhasználói autentifikáció, valamint a biztonságos üzemelést biztositó hardver és szoftverelemek és azok frissítései is.

\subsection{Az Ipar 4.0 és az IoT kapcsolata}

Napjainkban a dolgok internete (Internet of Things, azaz IoT) tartja lázban a világot. A szükséges kommunikációs és információs technológiák ma már képesek az internetre csatlakozó több milliárd eszközt és tárgyat támogatni, valamint az általuk generált hatalmas adatmennyiséget továbbítani, tárolni és feldolgozni. Ahogyan a közösségi hálókon az emberek tartják egymással a kapcsolatot, úgy a dolgok internetjén a legkülönbözőbb tárgyak, a gyártás vagy karbantartás alatt levő termékek is képesek információkat megosztani aktuális állapotukról. A digitális és a fizikai világot összekapcsoló rendszerek többek között beépített szenzorokat, vezeték nélküli kommunikációs képességeket, aktuátorokat és szemantikus termékmemóriát használnak [10].

\subsubsection{Az IoT alkalmazásának lehetőségei}

Az általunk kialakítandó rendszer a beépített szenzorok segítségével maga ellenőrzi a vizsgált anyag esetében, hogy a memóriájában tárolt követelmények miként teljesülnek, és azonnal riasztást küld, ha eltérést észlel. Így az általunk kialakítandó rendszer minden eddiginél jobban optimalizálhatóvá válik, de a lehetőségek ezzel még nem merülnek ki. Az intelligens eszközök olyan szolgáltatásokat is kínálhatnak az interneten, amelyekkel a gép-gép közötti (M2M) kommunikáció által különböző beavatkozásokat kezdeményezhetnek. A közvetlenségnek és azonnaliságnak köszönhetően rendszerünk dinamikusabbá teheti az erőforrásigények tervezését is. A Res-Com (Resource Conservation through Contextactivated

Machine-to-Machine Communication) projekt jól alkalmazható lehetne a rendszerünk elemeként, mert a munkaállomás vezeték nélküli kommunikációs kapcsolaton keresztül folyamatos adatkapcsolatot tart fenn az anyagvizsgálatát ellátó szenzorokkal, amelyek így aktívan befolyásolják a vasúti közlekedést. A vasúti szerelvények mint munkaállomás - amelyek integrált webszervereket is tartalmaznak - egymással is kapcsolatban állnak, így több szerelvényre vagy a vasúti közlekedés egészére is kiterjeszthető a folyamatokat összehangoló és optimalizáló, elosztott közlekedésirányítás. A Res-Com rendszer lehetővé teszi, hogy a vasút minden egyes, a vizsgálatban részt vevő szerelvények mindegyikét nyomon követve a méréseken kívül rendkívül nagy mennyiségü adatot gyüjtsön az erőforrások felhasználásáról is, és a valós idejü elemzésükkel nyert információkat egy szintén webalapú vizualizációs keretrendszer (Display-as-a-Service, DaaS) segítségével megjelenítse. Az így nyert betekintés alkalmat ad arra, hogy a vasút menet közben kiértékelje a folyamatok energiahatékonyságát, illetve alternatív lehetőségeket mérlegeljen, és szükség ese- 
tén azonnal beavatkozzon a közlekedés biztonsága fenntartásának érdekében. A DaaS egy keretrendszer, amely számos, egymástól eltérő forrásokból származó, vizualizált adatokat az interneten vagy belső hálózaton keresztül különböző eszközökön, igény szerinti összeállításban jeleníti meg. [10]

\subsubsection{Az IoT-gateway program-igény}

Az IoT-gateway az átalakítandó eszközt felügyelő szenzorokkal egészül ki, amelyek a vizsgált anyag paramétereit mérik. A szoftver e mért értékeket valós idejü információkká konvertálja, vagyis olyan formátummá, amely már az adott vasúti informatikai környezetbe integrálható mint egy „fáradhatatlan szinkrontolmács” az Ipar 4.0 irányába. Az IoT-gateway nem igényel bonyolult programozást, csupán konfigurálni szükséges egy böngésző használatával, ami a gyakorlatban azt jelenti, hogy igen gyorsan üzembe helyezhetö. A konfiguráció a közelmúltban megjelent, új nyílt PPMP gépi nyelven (Production Performance Management Protocol) zajlik. Az Ipar 4.0 számára ily módon „felfrissítve” a vasúti szerelvény immár kész a hálózatba kapcsolt közlekedés alapvető új lehetőségeire. Ezek egyike az állandó minőségbiztosítás érdekében végzett folyamatellenőrzés, míg egy másik a nem várt eseményeket megelőzni hivatott állapotfelügyelet [11].

\subsection{A mobiltechnológiás adatátvitel}

A GSM (Global System for Mobile Communication) szabvány a mobiltelefonok által használt második generációs digitális cellás kapcsolat alapú hálózati protokollok leírására került bevezetésre. A lassú adatátviteli sebesség és a technológia várható elavulása új generációs készülékekben megkérdőjelezi alkalmazását. A GSMcellák egy ideig nem lesznek lekapcsolva, mivel sok biztonságtechnikai és autóipari alkalmazás is használja ezt a technológiát, de a cellahálózat bővítése nem várható. A ma aktív cellák kikapcsolása legkésőbb 2026-ra várható [12].

Az Edge (Enhanced Data Rates for GSM Evolution) szabványt az adatátviteli sebesség egy új modulációs eljárással az átlagos GPRS adatátviteli sebesség háromszorosára - $100 \mathrm{kbit} / \mathrm{s}$ nagyságrendü értékre (max $236 \mathrm{kbit} / \mathrm{s}$ ) - való növelésével hozták létre. Az Edge a meglévő GSM/GPRS rádiós hálózathoz kötődik, emiatt annak esetleges kikapcsolása miatt nem feltétlenül érdemes ipari alkalmazásokban hosszú távon ezzel a technológiával számolni [12].

Az UMTS (Universal Mobile Telecommunications System) harmadik generációs mobil távközlési szabvány egy közbülső lépcsőt jelent a régebbi technológiák és az LTE között. Az UMTS bevezetése komoly beruházási háttérrel jár, mert új bázisállomásokat kell építeni. Ez a technológia a nagy sávszélessége miatt (max 384 kbit/s), nagyon kedvező, mert az előző verziókkal kompatibilis, mégis utat fog engedni az LTE (LongTermEvolution) szabványnak. Az LTE-cellák az UMTS-cellákkal ellentétben gombamód szaporodnak [12].

\subsubsection{A technológiák áttekintése}

GSM/GPRS-modulok az elkövetkező két évben piacra kerülő termékekhez, és LTE-modulok a távolabbi jövő alkalmazásaihoz. A GSM/GPRS az iparban széles körben elfogadott technológia, azonban a következő 10-15 évben kivezetésre kerül. Az LTE nem kompatibilis az előző GSM/GPRS vagy UMTS technológiákkal, valamint a magas modul ár is (mely a GSM modulokénak akár nyolcszorosa lehet) problémát jelent. A biztonságtechnikai alkalmazásokban, a mérőberendezésekben és az ipari folyamatirányításban a tapasztalat alapján a feltöltés sebessége a meghatározó. A szenzoradatok közvetítéséhez az IoT felhasználásoknál egy sor kommunikációnak kell zajlania, így a feladatok összetettsége miatt ipari alkalmazásokban egyre szélesebb sávú technológiákra van szükség, a 
jövő LTE-technológiáé. Az alkalmazó cégek elvárása a modulgyártók irányába az előző generációs (GPRS) készülékekkel való kommunikáció lehetőségének biztosítása és a müködés közben elérhető szoftver erőforrások kihasználhatósága azért, hogy a komplex hardver kialakítást ne kelljen megváltoztatni. Figyelembe véve, hogy Európa nagyobb területein az LTEtopológia jelenleg még nem mindenütt elérhető, javasolt az LTE-modulok mellett ezekhez a tartalék megoldásokhoz folyamodni, hogy a rendszerünk mindenhol müködőképes legyen. Nagy biztonsági kockázatot jelent az adatok továbbításában a szerelvények elérhetőségének kérdése hálózatkimaradás esetén. 2016 márciusának elején például a Vodafone hálózata Németország nagy területein elérhetetlenné vált. Azért, hogy ilyen esetekre is felkészüljünk, redundáns hálózati megoldást is be kell építeni a rendszerünkbe. A vezérlő nyílt pályán müködik, ahol nincs Ethernet hozzáférés: ilyen esetben a modul 2 multiplexelt SIM kártya bemenettel kell hogy rendelkezzen, amelyik közül az egyikbe egy alternatív szolgáltató SIM kártyája kerül [12].

\subsubsection{Az 5G technológia}

A felhasználók minden más technológiánál szélesebb körben fogadták el a 3G- és a 4G LTE-szabványt, ami nem egészen 15 év alatt csaknem hárommilliárd végpontot eredményezett. A friss előrejelzések szerint a kommunikációs eszközök száma 2020-ra meghaladja az 50 milliárdot, a mobil adatforgalom pedig mintegy 197000 PB (petabájt) lesz. [13]

Az 5G nem a meglévő technológiát kívánja kiváltani, így a $4 \mathrm{G}$ LTE-re továbbra is nagy feladat hárul majd. Az eltérő szabványokat egymáshoz kell igazítani. Az Európai Unió tagállamaiban létrehoznának egy Ipar 4.0 platformot, amelyeket európai hálózattá kötnének össze. Az Ipar 4.0 csak akkor kaphat komoly esélyt, ha az ügyfelek bízni fognak az új ajánlatokban és a cégekben, valamint azok adatkezelésében [14].

Az 5G-eszközök várhatóan 2020-ban kerülnek az átlag felhasználásra. A 25-80 GHz-es tartományban hihetetlen sebességek érhetőek el, ámde van egy hatalmas nehézsége ennek a spektrumnak: az eszköznek közvetlenül rá kell látnia az adótoronyra. A tesztek szerint a $28 \mathrm{GHz}$-en a sugárzás kisebb akadályokon (ablakokon, csapadékon, lombozaton) képes áthaladni, azonban komolyabb akadályokon (falakon) nem. Ezenkívül a tereptárgyakon a sugárzás nem visszaverődik, hanem elnyelődik. Az 5G-s eszközöknél egy gombelem vagy egy kisméretű napelem is elegendő lesz majd, ez pedig új felhasználási módokat, egészen új szenzorokat tesz lehetővé [15].

Az 1. táblázat a különböző mobiltechnológiák jellemzőit foglalja össze generációk szerint.

Új képesség az alacsony késleltetés, ami nagyon fontos az ipari vagy a jármüves felhasználásnál is, esetünkben a vasúti közlekedésben. Ugyanis egy alacsony késleltetésű hálózat esetében látszik az LTE és az 5G közötti különbség. Egy 90 km/h sebességgel haladó szerelvény az LTE tipikus 40 ezredmásodperces késleltetése alatt 1 métert tesz meg, míg az 5G 1 ms-nél is alacsonyabb késleltetése alatt csak 2,5 centimétert. Ez az adat a pontos adatszolgáltatás esetében nem elhanyagolható szempont [15].

A Surreyi Egyetem 5G Innovációs Központja szakembereinek, laboratóriumi körülmények között, sikerült másodperceként egy terabit adatot továbbítani vezeték nélkül [16].

A Samsung Electronics tesztjei során 28 $\mathrm{GHz}$ frekvencián 1,056 Gbps sebességgel adatokat két kilométer távolságra sikerült továbbítani, amelyhez 64 antennamodulra volt szükség, ezek segítségével tudta kiküszöbölni a magas frekvenciatartomány miatti jelterjedési veszteségét [17]. 
1. táblázat. A mobiltechnológia áttekintése [12]

\begin{tabular}{|c|c|c|c|}
\hline Generáció & Technológia & Átvitel & Letöltési sávszélesség \\
\hline $1 G$ & AMPS & analóg, kapcsolatalapú & - \\
\hline $2 G$ & GSM & digitális, kapcsolatalapú & $9,6 \mathrm{kbit} / \mathrm{s}$ \\
\hline $2.5 G$ & HSCSD & digitális, kapcsolatalapú & $57,6 \mathrm{kbit} / \mathrm{s}$ \\
\hline $2.5 G$ & GPRS & digitális, csomagkapcsolt & $115 \mathrm{kbit} / \mathrm{s}$ \\
\hline 2.75G & EDGE & digitális, csomagkapcsolt & $236 \mathrm{kbit} / \mathrm{s}$ \\
\hline 3G & UMTS & digitális, csomagkapcsolt & $384 \mathrm{kbit} / \mathrm{s}$ \\
\hline 3.5G & HSPA & digitális, csomagkapcsolt & $14,4 \mathrm{Mbit} / \mathrm{s}$ \\
\hline 4G & LTE & digitális, csomagkapcsolt & $150 \mathrm{Mbit} / \mathrm{s}$ \\
\hline $4 G$ & $\begin{array}{l}\text { LTE Advanced } \\
\text { (LTE-A) }\end{array}$ & digitális, csomagkapcsolt & 300-tól $600 \mathrm{Mbit} / \mathrm{s}$ \\
\hline 4.5G & $\begin{array}{l}\text { LTE Advanced } \\
\text { Pro (LTE-AP }\end{array}$ & digitális, csomagkapcsolt & $1 \mathrm{Gbit} / \mathrm{s}$ \\
\hline $5 G$ & $\begin{array}{l}\text { 5th generation } \\
\text { mobile networks } \\
\text { and wireless } \\
\text { systems }\end{array}$ & digitális, csomagkapcsolt & $\begin{array}{c}6 \mathrm{GHz} \text { alatt - } \\
6 \mathrm{Gbit} / \mathrm{s}\end{array}$ \\
\hline
\end{tabular}

\subsection{A felhőszolgáltatás integrálása}

A felhőszolgáltatás előnye, ami a digitalizáció alapját jelenti, hogy a szükséges információkhoz földrajzi kötöttségek nélkül hozzáférhetünk. Ugyan az Ipar 4.0 esetében forradalmi váltásról beszélünk, azonban sok esetben korábban már meglévő, eredményesen müködő struktúrák újraszervezéséről van szó, kiegészítve napjaink infokommunikációs megoldásaival és az ahhoz szükséges biztonsági követelményekkel. A mobil eszközök ipari alkalmazása vagy a felhőalapú kommunikáció elterjedése elősegíti azt a folyamatot, melynek eredményeként a hazai cégek is egyre szívesebben alkalmazzák a digitális megoldásokat, így a távkarbantartást is. Különösen abban az esetben, ha ez nem jelent számukra jelentős költségnövekedést [18] [19]. 


\section{Következtetések}

Az általunk leírt lehetőségek felhasználásával megépíthető az a rendszer, mely alkalmas lesz a vasúti felépítmény folyamatos monitorozására, segítve ezzel a közlekedés zavartalan és biztonságos üzemelését.

Jelenleg a tervezés szakaszánál tartunk, mely során a lehetőségek, igények és a megvalósíthatóság tanulmányozását végeztük el, ennek alapján egy tesztrendszert fogunk felépíteni, mely alkalmas lesz az eltérések felderítésére.

\section{Szakirodalmi hivatkozások}

[1] Wahlster, W.: Industry 4.0: The Semantic Product Memory as a Basis for CyberPhysical Production Systems. 2013.

[2] Bearing Point, Digitalization in the rail sector, letöltve: 2016.10.31. http://www.bearingpoint.com/ecomaXL/files/ Digitalization-in-the-railsector.pdf\& download $=0$

[3] Both T.: Bemutatkozik a Pályalétesitményi Technológiai Osztály Magyar Államvasutak Zrt., Sínek Világa, ISSN 0139-3618, 2012.

[4] Képforrása, letöltve: 2016.10.31. http://m.cdn.blog.hu/ma/mav/image/istvantel eki/IMG_20110717_195313.jpg

[5] MÁV Biztonsági Igazgatóság: Biztonsági Tájékoztató 2013. október

[6] Csiszár G., Fábián E.R., Ungár T., Dévényi L.: Hydrogen permeability with dislocation in low carbon, aluminium-killed, enamel-grade steels, International Journal Of Materials Research 103:(6) pp. 673-679. 2012.

[7] Enikö-Réka Fábián, Gábor Csiszár, Tamás Ungár: The Dislocation Density and the Dislocation Character Effect on the Hydrogen Permeability of Low Carbon Enamel-Grade Steel; Anyagok Világa 9:(2) pp. 1-9. (2011)

[8] Rajnai Zoltán, Fregan Beatrix: Kritikus infrastruktúrák védelme, A XXI. Fiatal Müszakiak Tudományos Ülésszaka előadásai. [Proceedings of the XXI-th International Scientific Conference of Young Engineers], Kolozsvár, Románia, 2016.03.17-2016.03.18. Kolozsvár: Erdélyi Múzeum-Egyesület (EME), 2016. pp. 349-352. (Müszaki Tudományos Közlemények; 5.)
[9] Gabor Vanderer, Zoltan Rajnai: Applicability Of Risk-Evaluation Theories In Critical Infrastructures, Trends and Innovations in Ebusiness, Education and Security: PROCEEDINGS Fourth International Scientific Videoconference of Scientists and $\mathrm{PhD}$. students or candidates., Bratislava Slovakia: Ekonomická Univerzita v Bratislave, 2015. pp. 82-90. http://webkonf.eu/index.php/en/archive/2015( letöltve: 2016.11.20.)

[10] Kis Endre: Ipar 4.0 - a jövö gyára, Gyártástrend.hu, 2013. április 14., http://www.gyartastrend.hu/informatika/cikk/ ipar 40 a jovo gyara, (letöltve: 201 $\overline{6} . \overline{1} 1 . \overline{20}$.)

[11] Bosch: A gépek többsége még nem az Ipar 4.0 része, 2016.11.09., http://www.techstorym2m.hu/a-gepektobbsege-meg-nem-az-ipar-4-0-resze.html, (letöltve: 2016.11.20.)

[12] Stefan Koltes, Kiss Zoltán: GSM technológia ipari felhasználásra, 2016.10.27., http://www.techstorym $2 \mathrm{~m} . \mathrm{hu} / \mathrm{gsm}$ technologia-ipari-felhasznalasra.html, (letöltve: 2016.11.20.)

[13] Lauri Oksanen, Amitava Ghosh: A jövö vezetékmentes kommunikációja, Magyar Elektronika, 2016. május 03., https://www.magyar-elektronika.hu/34tartalom/tartalom/1553-a-joevvezetekmentes-kommunikacioja, (letöltve: 2016.11.20.)

[14] Prioritás az $5 G$ bevezetése Európában, eGov Hírlevél, 2016. március 20., http://hirlevel.egov.hu/2016/03/20/prioritasaz-5g-bevezetese-europaban/, (letöltve: 2016.11.20.)

[15] Gálffy Csaba: 5G, ahogy Barcelonából látszik, HWSW, 2016. február 24., http://www.hwsw.hu/hirek/55227/5g-mwcmobilhalozat-gigabit-cella-ericsson-nokiahuawei.html, (letöltve: 2016.11.20.)

[16] 5G-n száz gigabájt lejön egy másodperc alatt, Origo, 2015.02.26., http:/www.origo.hu/techbazis/20150226-5gn-szaz-gigabajt-lejon-egy-masodpercalatt.html, (letöltve: 2016.11.20.)

[17] Peresztegi Gábor: 2020-ra 5G-t igér a Samsung, HWSW, 2013. május 13., http://www.hwsw.hu/hirek/50261/samsung- 
5g-mobil-adatatvitel.html,

(letöltve:

2016.11.20.)

[18] Dalnoki László: A digitalizáció a karbantartási folyamatokat is megújitja, 2016.11.20., http://www.techstorym2m.hu/adigitalizacio-a-karbantartasi-folyamatokat-ismegujitja.html, (letöltve: 2016.11.20.)

[19] Zoltán Rajnai, Edit Ruboczki: Moving Towards Cloud Security, Interdisciplinary Description Of Complex Systems 13:(1) pp. 914. (2015), http://indecs.eu/2015/indecs2015pp9-14.pdf, (letöltve: 2016.11.20.) 